\title{
A survey of management practices that influence calf welfare and an estimation of the annual calf mortality risk in pastured dairy herds in Uruguay
}

\author{
Carlos O. Schild, ${ }^{1 *}$ ๑( Rubén D. Caffarena, ${ }^{1,2} \odot$ Andrés Gil, ${ }^{2} \odot$ Javier Sánchez, ${ }^{3}$ Franklin Riet-Correa, ${ }^{1}$ \\ and Federico Giannitti ${ }^{1 *}$ (1) \\ ${ }^{1}$ Instituto Nacional de Investigación Agropecuaria (INIA), Plataforma de Investigación en Salud Animal, \\ Estación Experimental La Estanzuela Alberto Boerger, Ruta 50, km 11, 39173, Colonia, Uruguay \\ ${ }^{2}$ Facultad de Veterinaria, Universidad de la República (UDELAR), 11600, Montevideo, Uruguay \\ ${ }^{3}$ Department of Health Management, Atlantic Veterinary College, University of Prince Edward Island, Prince Edward Island C1A 4P3, Canada
}

\section{ABSTRACT}

Despite the importance of dairy farming in Uruguay, little information on dairy systems in this country is available in the scientific literature, and management practices that influence calf welfare at the herd level have not been explored. The aims of this study were to (1) describe the prepartum and calf-rearing systems, as well as the management practices that may influence calf welfare in pastured dairy herds in Uruguay, (2) estimate the annual calf mortality risk from birth to weaning, and (3) identify the primary clinical disease syndromes shown by the calves before death. A survey comprising a farm visit and a questionnaire was conducted on 225 randomly selected dairies with $>30$ milking cows, in 3 strata $(31-99,100-299$, and $\geq 300$ milking cows) of 6 Uruguayan departments where dairies are concentrated. Retrospective information from July 2013 to June 2014 was collected. A descriptive analysis was performed and results were inferred into the national dairy cattle population. Several management practices that could contribute to poor calf welfare were identified in a large proportion of farms. The annual calf mortality risk (calves that died between birth and weaning/calves born death or alive $\times 100$, $\mathrm{n}=149$ farms) was $15.2 \%$. Age at weaning averaged 75 d. Farmers reported that the most common clinical syndromes were diarrhea and respiratory disease in $85.2 \%$ and $47.5 \%$ of the farms, respectively. There was no continuous veterinary advice in $61.3 \%$ of the farms, $20.0 \%$ lacked data records, $38.5 \%$ had poor drainage in the prepartum area with waterlogging after rainfall, $52.1 \%$ monitored the prepartum area $\leq 2$ times per day

\footnotetext{
Received January 8, 2020.

Accepted May 26, 2020.

*Corresponding authors: cschild@inia.org.uy and fgiannitti@inia .org.uy
}

during the calving season, $65.1 \%$ did not perform navel antisepsis on newborns, $62.3 \%$ separated the calves from their dams at $>24 \mathrm{~h}$ postpartum, $95.2 \%$ did not have a colostrum management program, $72.4 \%$ did not rotate the calf-rearing areas, $59.0 \%$ did not disinfect the calf feeders, $85.7 \%$ did not have staff dedicated exclusively to calf rearing, and $39.8 \%$ did not separate sick from healthy calves. The average volume of milk or milk replacer offered per calf was $4.5 \mathrm{~L} /$ day. Several of the identified management practices that affect calf welfare in the prepartum and calf-rearing periods could explain the high mortality risk. An effort should be made to conduct extension work focusing on the dissemination of good management practices to improve calf welfare and reduce calf mortality in Uruguayan dairy farms. Key words: calf welfare, calf mortality, dairy farming, survey, Uruguay

\section{INTRODUCTION}

Dairy farming in Uruguay is socioculturally and economically important, as Uruguay is one of the top per capita consumers $(\sim 250 \mathrm{~L} /$ year $)$ of dairy products in Latin America (FAO-FEPALE, 2011), and approximately $70 \%$ of the milk produced in the country is exported. Dairy exports in 2018 totaled US $\$ 683$ million (INALE, 2019; MGAP-DIEA, 2019), accounting for $11.5 \%$ of all agricultural exports. Despite this, there is little information describing the general characteristics of the Uruguayan dairy sector in the scientific literature, and specific information on calf welfare, disease, and mortality, as well as on management practices in the prepartum and calf-rearing periods, is lacking.

Dairy farming systems in Uruguay are mainly pasture-based, with $75 \%$ of a calf's diet from farm-grown forage (Fariña and Chilibroste, 2019). Milk production grew linearly from 1985 to 2016 at a rate of $3.2 \% / y r$, with an attendant reduction in the number of farmers 
and the area allocated to dairy farming. This growth was due to increased stocking rates, milk production, and milking cow:dry cow ratio (MGAP-DIEA, 2019), indicating a production intensification process. However, the national dairy stock did not grow significantly over the past decade (MGAP-DIEA, 2019), which can partly be attributed to low reproductive efficiency, relatively high calf mortality, and high cow turnover rate, which have not been properly quantified.

Dairy calves are at an increased risk of disease and mortality in the perinatal and neonatal periods; significant animal losses can occur if management practices in these periods are suboptimal (Donovan et al., 1998; McGuirk, 2008; Bleul, 2011). Calf morbidity and mortality are indicators of poor animal welfare and are influenced by numerous factors including nutrition (Drackley, 2008; Seppä-Lassila et al., 2016; Kertz et al., 2017), health and immune status (Wells et al., 1997; Chase et al., 2008; Urie et al., 2018), hygiene (Marcé et al., 2010), neonatal care and colostrum management (Mee, 2008; Gundelach et al., 2009, Godden et al., 2019), occurrence of pathogens (McGuirk, 2008; Torsein et al., 2011), and other management practices (Jenny et al., 1981; Villettaz Robichaud et al., 2016). In production systems where parturition and calf rearing take place outdoors, weather conditions are additional factors that influence calf health and survival (Lundborg et al., 2005; Bleul, 2011; Cuttance et al., 2017b). Digestive and respiratory symptoms are the most commonly identified clinical problems in calves from birth to weaning in US dairies, with digestive issues peaking at 2 wk of age and respiratory symptoms becoming more prevalent later in the preweaning period (Urie et al., 2018). Information on mortality risk and clinical signs before death in Uruguayan dairy calves is lacking in the scientific literature.

Describing management practices at the farm level represents an initial step in assessing animal welfare issues (Vasseur et al., 2010). Surveys designed to identify problems in the prepartum and neonatal periods and to provide information with the aim of increasing calf welfare and production have been performed in various European (Svensson et al., 2006; Gulliksen et al., 2009; Raboisson et al., 2013), North American (Vasseur et al., 2010; USDA 2014), Oceanic (Cuttance et al., 2017b; Abuelo et al., 2019), and Asian (Kayano et al., 2016) countries. Similar information from South America is scarce and is limited to a few Argentinian (INTA CeRBAS, 2011) and Brazilian studies (Neto et al., 2004; Hötzel et al., 2014; Fruscalso et al., 2020).

Given the current scenario, the aims of this study were to (1) describe the prepartum and calf-rearing systems, as well as the management practices that may influence calf welfare in Uruguayan pastured dairy farms, (2) estimate the annual calf mortality risk from birth to weaning, and (3) identify the primary clinical disease syndromes shown by the calves before death.

\section{MATERIALS AND METHODS}

\section{Farm Selection}

In 2013, there were 3,225 dairy farms in Uruguay. For this study, farms with $\leq 30$ milking cows (MC) were excluded, which ruled out 1,243 farms (38.5\% of the total), but only $10.1 \%$ of the target MC population. The rationale for excluding small-scale dairies was that these mostly represent subsistence farmers that generally do not commercialize milk to the industry, and are overrepresented by artisanal cheesemakers that process the milk produced on their farms. Thus, our study represents commercial dairies. Additionally, the study focused on 6 departments (Canelones, Colonia, Florida, Paysandú, Río Negro, and San José) that contained $74 \%$ of the target MC population (MGAPDICOSE, 2013). This resulted in the sampling frame being reduced to 1,677 farms. These farms were stratified according to the number of MC (herd size) in 3 strata: 31 to 99,100 to 299 , and $\geq 300$. The sample size calculation to estimate a calf mortality risk of $20 \%$ with a maximum error of $5 \%$ and a confidence level of $95 \%$ was 232 farms. An additional 10\% of farms were included in each MC stratum, to eventually compensate for farms refusing to participate in the survey, accounting for a total of 255 farms (85 per stratum). Dairy farms within these 6 departments and $3 \mathrm{MC}$ strata were randomly selected using the command "sample" of STATA (StataCorp, Texas) from the database of the Ministry of Livestock, Agriculture, and Fisheries (Ministerio de Ganadería, Agricultura y Pesca, MGAP; https:// www.gub.uy/ministerio-ganaderia-agricultura-pesca/), where all dairy farms of the country are identified with a individual identification number (DICOSE: Division Contralor y Semovientes; https://www.gub.uy/ tramites/presentacion-declaracion-jurada-dicose).

\section{Survey}

The survey included a visit to each farm and the application of a questionnaire via a personal interview that lasted 1 to $1.5 \mathrm{~h}$ with the owner, staff, veterinarians, agronomists, and agricultural technicians working at each farm. Staff familiar with the day to day operations were present at all farm visits. During the visits, data records kept at each farm were retrieved by the staff and revised by and made available to the pollsters.

The questionnaire was initially designed and written by veterinarians and researchers from the Uruguayan 
Instituto Nacional de Investigación Agropecuaria and subjected to rounds of revisions and external validation by a committee formed by large animal veterinary practitioners working with dairy cattle in Uruguay and Argentina, veterinarians and agronomists from the Facultad de Veterinaria, Universidad de la República, Uruguay (FVET-UDELAR), Sociedad de Medicina Veterinaria de Uruguay (SMVU), and the Uruguayan Ministerio de Ganadería, Agricultura y Pesca (MGAP), as well as veterinary researchers from the Argentinean Instituto Nacional de Tecnología Agropecuaria (INTA).

Initially, the survey was subjected to a pilot trial in 4 farms, after which minor adjustments were made. All farms were visited once between June 1, 2015 and February 2,2016 , and retrospective information was gathered from the period spanning July 1, 2013 to June 30, 2014. Data on management practices in the prepartum and calf-rearing periods were collected, including type of rearing systems, housing, staff, colostrum management, feeding practices, hygiene, health, and sanitary events (including management of sick calves, clinical signs, and data to estimate the annual mortality risk of calves from birth to weaning). For annual calf mortality risk calculation (see below), data records kept by each farmer were retrieved and revised. Specifically, the number of dams that calved, the number of calves born dead or alive, and the number of calves that died in the rearing period (before weaning) during the study period were retrieved. Whether male and female (or only female) calves were routinely raised in the farms and, in farms that only raised female calves, whether male calves were routinely culled or sold for meat production, was also assessed. The data collected in the survey are summarized in Supplemental Table S1 (https://doi .org/10.3168/jds.2020-18177). All data were entered into a digital database in Excel 2013 (Microsoft Office) using Google forms (https://www.google.com/forms/ about/).

\section{Pollsters}

All surveys were conducted by 2 veterinarians (C. O. Schild and R. D. Caffarena) with experience in production medicine and bovine health management and a thorough understanding of dairy production and calfrearing systems. The pilot trial and the first 50 surveys were conducted by both veterinarians simultaneously, and the remainder of the surveys were conducted by both pollsters independently of each other.

A descriptive analysis of the variables collected in the survey (Supplemental Table S1, https://doi.org/10 $.3168 /$ jds.2020-18177) was performed. The number of calves that died at birth or during rearing before weaning (which on average occurred at d 75 of life as reported by farmers) and the total number of births during the study period were used to calculate the annual calf mortality risk, as follows: total number of calves that died between birth and weaning from July 1, 2013 to June 30, 2014/total number of calves born dead or alive in the same period $\times 100$. Healthy calves that were culled or sold early after birth (i.e., male calves that are sold to beef farms for meat production) were excluded from the calculation. Only farms with complete data for number of calvings, number of calves born dead or alive, calving dates, number of reared calves, and number of dead calves in the study period were used to estimate the mortality risk. The estimated calf mortality risk and the proportions of farms with different characteristics and variables collected in the survey (as shown in Tables 1-4) were inferred for the national dairy cattle population by weighting the number of dairy farms surveyed in each MC stratum. To assess differences in the annual calf mortality risks among MC strata, a Pearson's Chi-squared test corrected by the survey design was performed; $\alpha=0.05$ was set for significance level. The descriptive analysis and Chi-squared test were performed in STATA (StataCorp, Texas).

\section{RESULTS AND DISCUSSION}

Of the 255 selected farms, 225 were visited and surveyed. The remainder had recently gone out of business or refused to participate in the study. The results of the survey were split into 6 sections, which are presented below. Surveys such as the one performed in this study allow critical points in calf-rearing systems and management practices to be detected, and represent a starting point for decision-making on actions to improve animal welfare, health, and production (Vasseur et al., 2010).

\section{General Characteristics of the Farms}

The 225 surveyed farms were located in the departments of San José (29.6\%), Florida (27.0\%), Colonia (22.6\%), Río Negro (8.4\%), Canelones (8.0\%), and Paysandú (4.4\%). The number of MC (missing data; MD: 1) ranged from 31 to 2,700 , with a mean of $134(95 \%$ CI: $124-140)$, and a median of 128 with an interquartile range of 263. In the year of the study, throughout the entire country, there were a total of 3,225 dairy farms, with a mean of $120 \mathrm{MC}$, and 1,982 dairy farms with $>30 \mathrm{MC}$ with a mean of $173 \mathrm{MC}$ (MGAP-DICOSE, 2013). Holstein (99.4\%; 95\% CI: 97.4-99.8\%), Jersey (12.9\%; 95\% CI: 8.7-18.5\%), and Holstein-Jersey crosses (18.7\%; 95\% CI: $13.5-25.3 \%)$ were the most common breeds in 221 farms (MD: 4). Milking cows were fed pasture only or pasture with supplementa- 
tion in $89.9 \%$ (95\% CI: $84.3-93.6 \%$ ) of farms (MD: 2 ), and the diet was based on ration (mostly silage) with pasture complementation in the remaining $10.1 \%$ of farms (95\% CI: 6.4-15.7\%). Regarding the breeding season, $50.4 \%$ (95\% CI: $42.3-57.9 \%$ ) of the farms (MD: 3) performed continuous breeding and, therefore, had calving throughout the year. The breeding period was semi-continuous (from June to January) in $43.5 \%$ of the farms (95\% CI: $36.2-51.0 \%$ ), and seasonal (from June to August in cows, and from July to August in heifers) in $6.2 \%$ of farms (95\% CI: $3.4-10.9 \%$ ). Overall, the surveyed farms were a good representation of the national commercial dairy farms of Uruguay (Fariña and Chilibroste, 2019; MGAP-DICOSE, 2013; MGAPDIEA, 2019), as expected with the random sampling.

The veterinary practitioner visited the farm at least once per month in $38.7 \%$ (95\% CI: $32.0-45.7 \%$ ) of the farms (MD: 1), and the remaining $61.3 \%$ (95\% CI: $54.3-68.0 \%$ ) of farms only consulted veterinarians sporadically when herd health issues were evident or had no veterinary advice at all. Veterinary advice is crucial to improve animal health, welfare, nutrition, and reproduction (Derks et al., 2014; Sumner and Von Keyserlingk, 2018).

Only $16.6 \%$ (95\% CI: $12.2-22.1 \%$ ) of the farms had complete records of the entire prepartum and calfrearing periods, which included birth dates, correct identification of calves and dams, sex, calving problems (dystocia), clinical manifestations of disease, medical treatments, age of death, and age at weaning. In $63.4 \%$ (95\% CI: $56.2-70.2 \%)$ of the farms these records were somewhat incomplete (for instance, with some missing variables or some weeks or months without detailed records), and $20.0 \%$ (95\% CI: $14.5-26.8 \%$ ) of the farms had no records whatsoever. The types of records included notebooks (paper) in 58.5\% (95\% CI: 51.0-65.7\%) of the farms, notebooks and dairy herd management software (i.e., Syscordwin, Macoel, or DHMS) in $18.0 \%$ (95\% CI: $13.1-24.3 \%$ ) of the farms, and notebooks and Excel spreadsheets (Microsoft, Redmond, WA) in 3.4\% (95\% CI: 1.6-7.1\%) of the farms. An effort should be made to improve data recording that allows for the identification of problematic animals, accurate estimations of morbidity and mortality, detection of critical points, decision-making, and setting short- and longterm goals, all of which improve the overall efficiency of the farm (Schuenemann et al., 2013).

\section{Prepartum and Partum}

In $98.7 \%$ (95\% CI: $95.2-99.7 \%)$ of the farms, calving occurred in outdoor collective pens, and animals also had access to a maternity pen in the remaining $1.3 \%$ (95\% CI: $0.3-4.8 \%)$ of farms. Offering dams and staff a comfortable place for calving and working, respectively, allows better monitoring of births, identification of dams necessitating assistance during parturition, and facilitation of colostrum management and newborn calf care (Gundelach et al., 2009; Schuenemann et al., 2011; Mee et al., 2014).

In $38.5 \%$ (95\% CI: $31.4-46.0 \%$ ) of the farms, the prepartum area had poor water drainage, and it was reported that these areas remained waterlogged or flooded after rainfall. Improving the drainage of the prepartum area can help improve the welfare and survival of calves and dams; as in dry environments, energy requirements for temperature regulation are lower than in wet and cold environments (Rodríguez et al., 2011). Considering that $96.6 \%$ (95\% CI: $94.2-98.0 \%$ ) of the farms did not have staff working exclusively in the prepartum area, and that $52.1 \%$ (95\% CI: 44.4-59.6\%) did not monitor the pregnant dams in the prepartum area more than twice per day (Table 1), it is possible that the parturitions needing intervention are not handled in a timely manner, and that calves born at night might have a higher risk of not receiving colostrum quickly enough to obtain an adequate transfer of passive immunity (von Keyserlingk and Weary 2007; Vasseur et al., 2010). Increasing the frequency of prepartum monitoring, mainly during night hours, as well as having staff working exclusively in the prepartum area, ensure fast intervention in dystocia and improve newborn calf care (Mee, 2008; Schuenemann et al., 2011). The duration of the dry period, some characteristics of the prepartum area and practices, and the staff responsible for calving in the surveyed farms are summarized in Table 1.

\section{Newborn Calf Care}

Early $(<4-6$ h) calf-dam separation after delivery has been regarded as beneficial to ensure early colostrum administration (McGuirk and Collins, 2004) and to avoid transmission of pathogens from dams to calves (Mee, 2008). Separation at $<24 \mathrm{~h}$ of life is less stressful for both the calf and the dam than separation at later stages (Weary and Chua, 2000; Flower and Weary, 2001). Conversely, in our study, calves were separated from their dams after $24 \mathrm{~h}$ of life in $62.3 \%$ of farms (Table 1). Information on newborn calf care is summarized in Table 2. Colostrum was systematically administered to all calves in only 20 of the surveyed farms, representing $4.8 \%$ (95\% CI: $2.7-8.6 \%$ ) of the farms (MD: 1 ). The remainder (95.2\%; 95\% CI: 91.4-97.3\%) allowed calves to suckle colostrum directly from the udders of their dams, and only under certain circumstances was colostrum obtained from the dam and administered to the calves, for example, when a calf was born weak. When calves suckle colostrum directly from the dam, 
Table 1. Main characteristics of the prepartum period in the surveyed farms

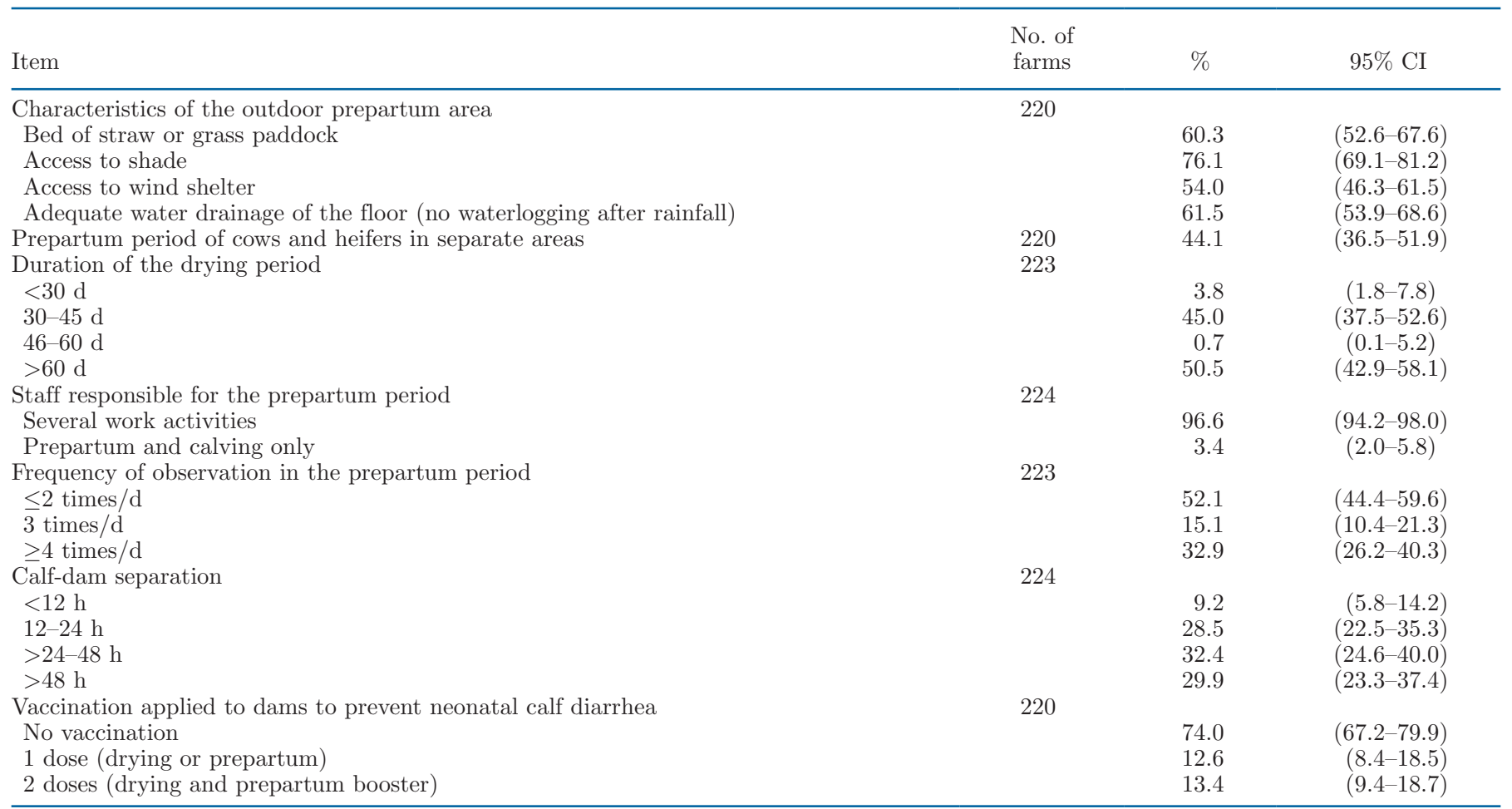

the volume and quality of the ingested colostrum as well as the time of ingestion, which are key in successful colostrum management programs, are not controlled (McGuirk, 2008; Godden et al., 2019). Under these circumstances, there is increased risk of failed transfer of passive immunity (FTPI). In addition, ingesting colostrum directly from the udder increases the risk of disease transmission to calves (Stewart et al., 2005).

In the few farms where all calves were systematically fed colostrum $(4.8 \%$; 95\% CI: $2.7-8.6 \%, \mathrm{n}=20$ surveyed farms), an average total of $3.4 \mathrm{~L}$ (95\% CI: $2.3-4.5$
L) of colostrum was administered. This average value is below or in the low range of the recommended value of 10 to $12 \%$ of BW at birth (USDA, 2007; Vasseur et al., 2010; Godden et al., 2019), considering an average birth weight of $\sim 40 \mathrm{~kg}$ for Holstein calves. Of the farms that systematically fed colostrum (4.8\%; 95\% CI: $2.7-8.6 \%$, $\mathrm{n}=20$ surveyed farms), $81.7 \%$ (95\% CI: $54.4-94.2 \%$ ) declared administering the first colostrum intake before $6 \mathrm{~h}$ of life, and $18.3 \%$ (95\% CI: $5.6-45.6 \%$ ) between 6 and $12 \mathrm{~h}$ of life. Farmers reported that colostrum quality was assessed in $80.5 \%$ (95\% CI: $48.1-94.7 \%)$ of

Table 2. Newborn calf care and colostrum management practices in the surveyed farms

\begin{tabular}{lccr}
\hline Item & $\begin{array}{l}\text { No. of } \\
\text { farms }\end{array}$ & $\%$ & $95 \%$ CI \\
\hline $\begin{array}{l}\text { Colostrum evaluation method } \\
\quad \text { No evaluation }\end{array}$ & 20 & 41.7 & $(21.7-64.8)$ \\
$\quad \begin{array}{l}\text { Direct observation } \\
\quad \text { Refractometer or lactodensimeter }\end{array}$ & & 38.8 & $(22.6-58.0)$ \\
$\quad$ Colostrum storage & 19 & 19.5 & $(5.3-51.1)$ \\
$\quad \begin{array}{l}\text { Pool } \\
\quad \text { Individual }\end{array}$ & & 26.8 & $(15.0-43.1)$ \\
$\quad$ Colostrum storage method & 19 & 73.2 & $(56.9-85.0)$ \\
$\quad$ Frozen & & 10.1 & $(3.3-27.2)$ \\
$\quad$ Booled & & 72.4 & $(55.2-84.8)$ \\
$\quad$ Colostrum pasteurization & 20 & 17.5 & $(8.0-33.9)$ \\
$\quad$ Yes & & 18.8 & $(5.9-46.2)$ \\
$\quad$ No & & 81.2 & $(53.8-94.1)$ \\
\hline
\end{tabular}


these farms, and that there was room for improvement in the remaining $19.5 \%$ (95\% CI: $5.3-51.1 \%$ ) of farms that did not assess colostrum quality, which should be discouraged (Vasseur et al., 2009; Godden et al., 2019). In only $31.6 \%$ (95\% CI: $13.2-58.3 \%$ ) of the farms that systematically fed colostrum to all calves, farmers reported that they assessed the percentage of calves with FTPI, which, according to the interviewees, varied from 10 to $30 \%$ (these records were not reviewed by the pollsters). In these farms, FTPI was assessed by refractometry in calf serum with a cutoff of $<8.5$ degree Brix. The reported FTPI values are higher than those suggested in Godden et al., (2019) that recommends that, in a good colostrum management program, FTPI should affect $\leq 10 \%$ of the calves. A study from New Zealand, where the predominant dairy farming systems are also pasture-based with cows calving outside and calves left on cows for approximately $24 \mathrm{~h}$, reported FTPI in a higher proportion of calves $(33.1 \%$ of 3,819 calves, ranging from 5-83\% in 107 farms; Cuttance et al., 2017a). The results generated in our study were probably biased toward underestimation of FTPI, as only a few farms systematically fed colostrum and assessed the calves for FTPI, and these are usually represented by the more proactive farmers. Arguably, the percentage of calves with FTPI could have represented an indirect indicator of poor animal welfare in newborn calves. Only $47.1 \%$ (95\% CI: $11.7-85.6 \%$ ) of the farms that systematically fed colostrum to all calves administered $\geq 4 \mathrm{~L}$ of high-quality colostrum before $12 \mathrm{~h}$ of life, as is widely recommended (Lorenz et al., 2011; Godden et al., 2019). Other colostrum management practices are shown in Table 2.

Navel antisepsis in newborn calves was performed in $34.9 \%$ (95\% CI: $28.4-42.0 \%$ ) of farms (MD: 2), which could partially explain why a relatively high proportion (15.7\%; 95\% CI: $10.1-22.1 \%)$ of these farms indicated that omphalitis was an important health problem during the rearing period (see section on clinical signs below). Omphalitis can lead to delayed growth, septic arthritis, and umbilical hernias (Mee, 2008). Jorgensen et al. (2017) observed that farms practicing navel disinfection in newborn calves had a lower mortality risk (average $=3.0 \%)$ than those not following the practice (average $=7.3 \%)$.

\section{Housing Systems, Staff, Biosecurity, and Disinfection of the Calf-Rearing Area}

Calf rearing was performed in outdoor systems in 97.9\% (95\% CI: $95.3-99.1 \%$ ) of farms. The calf housing systems were classified according to whether calves were housed individually or in group pens; $31.8 \%$ (95\%
CI: $25.2-39.5 \%$ ) of the farms used only individual housing, $11.7 \%$ (95\% CI: $7.5-17.7 \%$ ) of farms used only group pens, and $56.6 \%$ (95\% CI: $48.9-63.9 \%$ ) of farms alternated between individual and group housing. Although group pens allow for better expression of animal behavior compared with individual pens (Hötzel, et al., 2014), they also have inherent risks, such as a greater potential for pathogen transmission (Stull and Reynolds, 2008), as animals that share the same environment, water wells, and feeders have greater opportunities for direct and indirect contact among themselves, and with their fecal excretions, urine, and saliva. In individual systems, pathogen transmission is also possible, particularly when the rearing areas or the cages or stakes are not rotated, when the feeders are shared, or when these elements are not disinfected correctly (Marcé et al., 2010).

Only $14.3 \%$ (95\% CI: $10.3-19.5 \%$ ) of farms had staff dedicated to raising calves as their only work activity on the farm, and the remaining $85.7 \%$ (95\% CI: $77.3-$ $88.6 \%$ ) of farms had the staff that raised the calves also perform other tasks, including prepartum monitoring, newborn calf care, milking, and other activities such as heat detection, insemination, or feeding the cows. Thus, understaffing, perhaps as a consequence of the relatively high labor costs in Uruguay, possibly influenced calf welfare, as several time-consuming calf management practices may not have been performed correctly. Having qualified, motivated, trained, and dedicated staff is key to succeeding in efficient calf rearing (Rodríguez et al., 2011; Schuenemann et al., 2013).

Rotation of the calf-rearing area was practiced in only $27.6 \%$ (95\% CI: $21.3-35.0 \%$ ) of farms. Separating sick from healthy calves, disinfecting feeders and feeding equipment, and disinfecting soil should be encouraged in farms that do not already perform these practices, which accounted for 38.9\% (95\% CI: 32.647.6\%), $59.1 \%$ (95\% CI: $51.4-66.3 \%$ ), and $75.4 \%$ (95\% CI: $69.2-80.7 \%$ ) of farms (MD: 3), respectively, in the present study. Only $1.0 \%$ (95\% CI: $0.2-4.6 \%$ ) of farms (MD: 4) used a footbath with disinfectant for staff at the entrance and exit of the calf-rearing area to reduce the spread of pathogens. Independently of the housing system, periodically cleaning the feeders and removing the food rejected by calves, rotating the rearing area, moving the individual housing systems, disinfecting the soil, and adding new bedding all reduce the risk of exposure and transmission of pathogens (McGuirk, 2008; Rodríguez et al., 2011).

The average age at weaning reported by farmers was 75 d (95\% CI: $72-78$ d, interquartile range: 30$)$. Gradual weaning for several days was practiced by $74.1 \%$ (95\% CI: $66.8-80.2 \%$ ) of the farms, and abrupt wean- 
ing was practiced in $25.9 \%$ (95\% CI: $19.8-33.2 \%$ ) of farms. Abrupt weaning is stressful for calves (Vasseur et al., 2010) and should be discouraged to improve calf welfare. Other characteristics of the calf-rearing areas are summarized in Table 3.

\section{Calf Feeding}

The dairy diet in the farms was supplied at an average of $4.5 \mathrm{~L}$ of milk or milk replacer per day (95\% CI: 4.4-4.7 L/day). Supplying $4 \mathrm{~L}$ of milk or milk replacer per day has been associated with hunger (Viera et al., 2008), low growth, and poor health in calves (Khan et al., 2011). Soberon and Van Amburgh (2013) observed that calves receiving 6 to $8 \mathrm{~L}$ of milk or milk replacer per day had higher growth rates and BCS, earlier puberty, and greater milk production during first lactation.

The types of dairy diet offered to calves included milk replacer in $37.2 \%$ of farms (95\% CI: $30.3-44.6 \%$ ) and tank whole milk in $26.9 \%$ (95\% CI: $20.5-34.4 \%$ ). However, most farms $(68.2 \%$; $95 \%$ CI: $60.6-74.9 \%)$ offered waste (nonsaleable) milk from sick cows or cows in the transition period. Waste milk has lower nutritional quality, increases the risk of pathogen transmission (McGuirk, 2008), and can also lead to a reduction in antibiotic efficiency, favoring the emergence of antibiotic resistance (INTA CerBAS, 2011; Kertz et al., 2017) or disturbances in the function of the gastrointestinal tract (Le Cozler et al., 2012). Regarding pathogen transmission, an alternative method of reducing the bacterial load of waste milk is pasteurization (Godden et al., 2005; Armengol and Fraile, 2016), which was practiced in $18.8 \%$ (95\% CI: $5.9-46.2 \%$ ) of farms.
Regarding the use of solid feeds, $72.0 \%$ (95\% CI: 64.5-78.4\%) of the farms offered calf starters, $66.6 \%$ (95\% CI: $59.0-73.4 \%)$ of the farms offered hay or grass, and $4.6 \%$ (95\% CI: $2.6-8.0 \%$ ) of the farms offered prestarters. Interestingly, $23.2 \%$ (95\% CI: $17.2-30.5 \%$ ) of farms offered the MC ration to the calves; this practice should be discouraged because these rations generally have a protein content that is insufficient (16-18\%) to cover the protein requirements of neonate calves (NRC, 2001).

In the present study, $11.1 \%$ (95\% CI: $7.1-17.1 \%)$ of farms did not offer water to calves. This practice should be discouraged as it increases the risk of dehydration, mainly during episodes of diarrhea or warm temperatures. Water is a basic requirement that cannot be replaced by milk or milk replacer and must be offered fresh and ad libitum from birth (Stull and Reynolds, 2008; Kertz et al., 2017).

\section{Calf Mortality Risk, Clinical Signs, and Health- Related Management Factors}

The overall annual calf mortality risk from birth to weaning (0-75 d of life), including deaths that occurred during calving, was $15.2 \%$ (exact binomial CI: 13.4-17.2\%; range: $0-50 \%$; $\mathrm{n}=149$ farms; $\mathrm{MD}: 76$ ), as shown in Figure 1 and Table 4. The mortality risk in the median farm was $13.7 \%$ (Figure 1). Only farms with complete records and farms with incomplete records that had complete data for number of calvings, number of calves born dead or alive, calving dates, number of reared calves, and number of dead calves (n $=149$ farms) were used to estimate the calf mortality

Table 3. Main characteristics and management practices in the calf-rearing areas of the surveyed farms

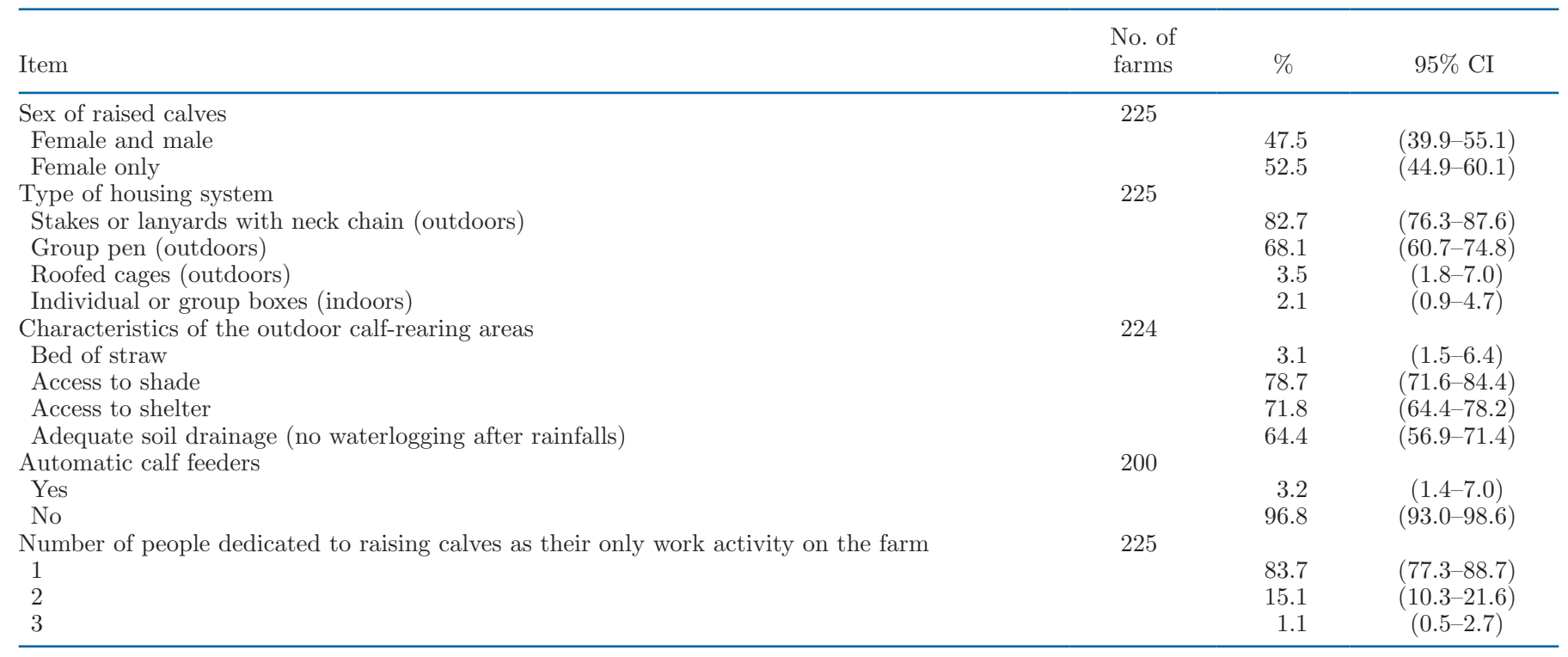


Table 4. Number of farms surveyed to estimate the annual calf mortality risk and total number of dairies in each milking cow stratum, which was used to infer the mortality risk of the national dairy cattle population

\begin{tabular}{lccc}
\hline & $\begin{array}{c}\text { Number of } \\
\text { farms surveyed }\end{array}$ & $\begin{array}{c}\text { Total number of dairies } \\
\text { with }>30 \text { MC in } 6 \\
\text { Uruguayan departments }\end{array}$ & $\begin{array}{c}\text { Annual calf } \\
\text { mortality risk \% } \\
\text { (exact binomial CI) }\end{array}$ \\
\hline $31-99$ & 59 & 1,099 & $14.6(12.0-17.4)$ \\
$100-299$ & 41 & 451 & $16.8(14.2-19.7)$ \\
$\geq 300$ & 49 & 127 & $15.3(13.4-17.4)$ \\
Total & 149 & 1,677 & $15.2(13.4-17.2)$ \\
\hline${ }^{1}$ MC = milking cows. &
\end{tabular}

risk. When considering only data from farms that had complete records $(\mathrm{n}=59)$, the estimated annual calf mortality risk was higher $(17.1 \%, 95 \%$ CI: $12.3-21.9 \%)$. Currently, mortality risk is considered one of the best and most reliable indicators of poor animal welfare (Sandgren et al., 2009; Nyman et al., 2011; de Vries et al., 2014). The mortality risk found in our study was a strong indicator of poor calf welfare in Uruguayan dairies. However, it should be noted that $20 \%$ of the farms in the present study reported annual calf mortality risks of $\leq 8 \%$ (Figure 1), indicating that reducing the risk of mortality is achievable in the country. The annual calf mortality risk did not differ significantly $(P$ $=0.30$ ) among the $3 \mathrm{MC}$ strata (Table 4).
The clinical symptoms that farmers reported calves displayed before dying were diarrhea $(85.1 \%$ of farms; 95\% CI: $78.5-90.0 \%)$, coughing (47.5\% of farms; $95 \%$ CI: $40.0-55.1 \%)$, weakness ( $15.8 \%$ of farms; $95 \% \mathrm{CI}$ : 11.0-22.1\%), omphalitis (15.7\%; 95\% CI: 10.9-22.1\%), red urine - consistent with hemoglobinuria-(10.9\% of farms; $95 \%$ CI: $7.2-16.4 \%$ ), abdominal distension (6.8\% of farms; $95 \%$ CI: 3.8-11.9\%), and neurologic signs (3.4\% of farms; $95 \%$ CI: $1.6-7.9 \%)$. Several infectious and parasitic etiologic agents may be involved in diarrhea or respiratory disease, as well as management practices that favor exposure to these agents or FTPI. In studies on neonatal diarrhea in Uruguayan dairy calves of up to $30 \mathrm{~d}$ of age, the main agents found were

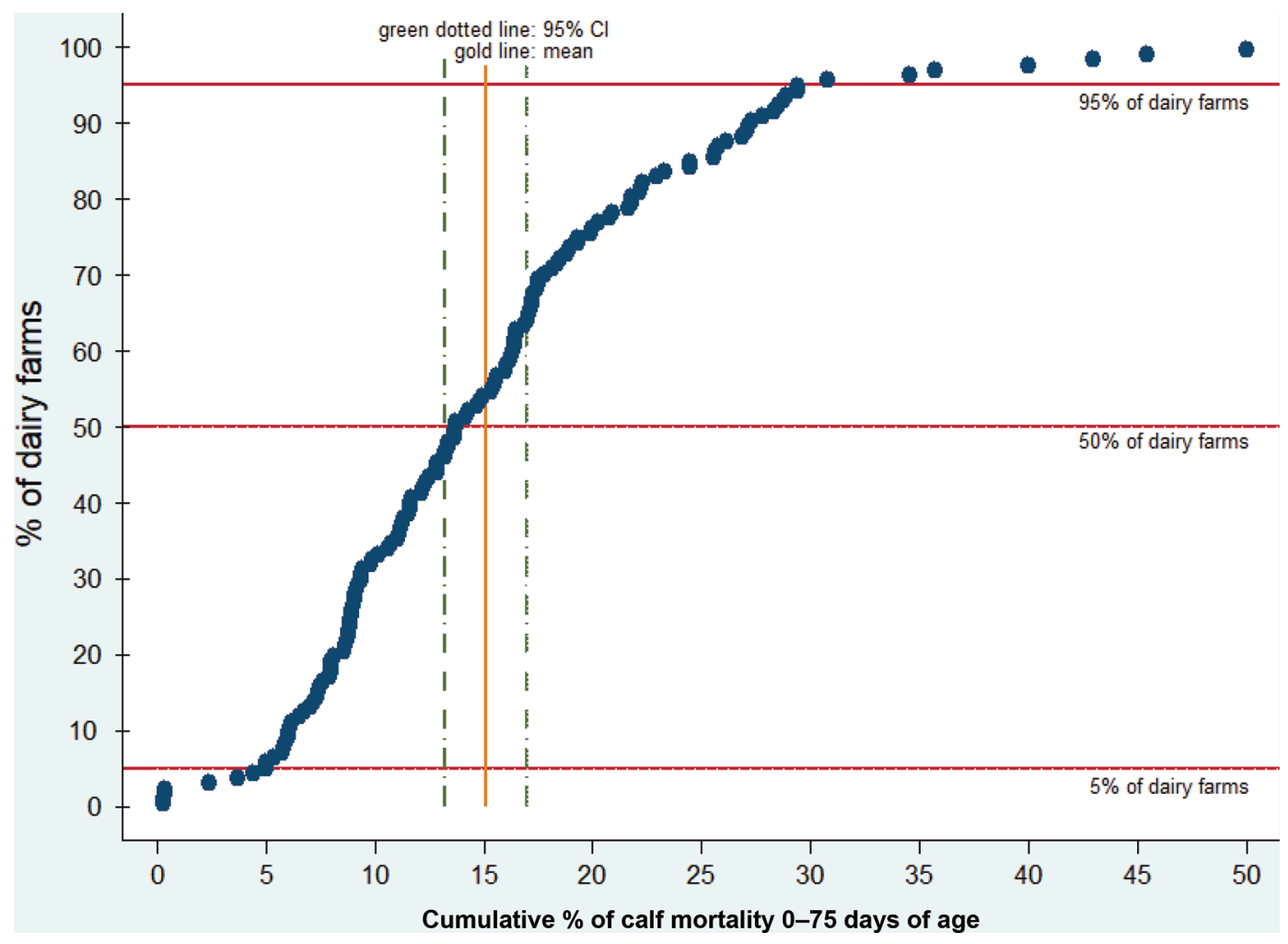

Figure 1. Calf mortality from 0 to $75 \mathrm{~d}$ of age. 
Cryptosporidium spp., rotavirus, and, to a lesser extent, Salmonella enterica, Escherichia coli, and bovine coronavirus (Caffarena, 2017; Casaux, 2018; Castells et al., 2018).

The main season associated with calf deaths reported by farmers (MD: 4) was winter in $65.4 \%$ (95\% CI: $57.7-72.4 \%)$ of farms, followed by summer $(3.2 \%$ of farms; $95 \%$ CI: $1.3-7.6 \%)$, spring (2.7\% of farms; $95 \%$ CI: $1.1-6.5 \%)$, and autumn (2.5\% of farms; $95 \% \mathrm{CI}$ : $1.3-5.0 \%)$. This could represent a bias due to higher concentrations of births in autumn and winter, resulting in an increase in the population of young calves exposed to the risk of dying in the first weeks of life, or a greater risk of death in winter, as previously described (Raboisson et al., 2013). Regarding weather events, $68.1 \%$ (95\% CI: $60.5-74.9 \%$ ) of farms (MD: 1 ) associated the occurrence of deaths with rainfall, $62.3 \%$ (95\% CI: $54.6-69.4 \%)$ of farms associated death with cold, and $6.4 \%$ (95\% CI: 3.5-11.4\%) of farms associated death with extreme heat. In the period assessed in this study (July 1, 2013-June 30, 2014), the average accumulated annual rainfall was $1,734 \mathrm{~mm}$, which is 436 $\mathrm{mm}$ greater than the average of the annual rainfall from 2006 to 2016 (1,298 mm; INIA, 2019); it is possible that this relatively high rainfall favored calf mortality, as most farms used outdoors housing systems for calves. A study in pasture-based dairy herds in New Zealand found that perinatal calf mortality was greater in calves born on days with greater rainfall (Cuttance et al., 2017b).

In $26.9 \%$ (95\% CI: $20.9-33.8 \%$ ) of farms, antibiotics were administered to all calves during neonatal diarrhea outbreaks via milk, regardless of whether they were sick or healthy at the time of treatment. Making accurate clinical and etiologic diagnoses to establish correct medical treatments is necessary, as diarrhea is a major cause of mortality in neonates (McGuirk, 2008; Heinrichs and Heinrichs, 2011). Additionally, using antibiotics preventively in healthy animals should be discouraged, as it induces the development of antimicrobial resistance (Casaux, 2018; Woolums et al., 2018). Interestingly, antibiotic resistance, including multidrug resistance, has recently been reported in Salmonella enterica isolated from calves in Uruguayan commercial dairies (Casaux et al., 2019).

The vaccinations applied to prevent neonatal calf diarrhea are shown in Table 1. Only 2.2\% (95\% CI: 1.1-4.4\%) of farms (MD: 5) artificially fed colostrum systematically to all calves and vaccinated the cows both at drying and in the prepartum (booster) period to prevent neonatal calf diarrhea. In this context, it is likely that the immunity generated by cows due to the vaccine is not properly transferred passively to calves through colostrum (Chase, 2008; Godden et al., 2019).

\section{Limitations of the Study}

Data collection was one of the main challenges we faced during this study. As stated before, many of the farmers we surveyed lacked data records, and many others had data that had to be retrieved manually from notebooks or Excel spreadsheets. For this reason, the annual calf mortality risk was calculated using data from a subset of farmers that kept enough information to allow for mortality risk to be calculated. Another challenge of quantifying calf mortality on dairy farms was related to the several definitions that have been proposed for mortality of calves under $1 \mathrm{yr}$ of age, which seems to have a large effect on the magnitude of mortality (Santman-Berends et al., 2019). The calf mortality risk estimated in our study grouped perinatal mortality (including death of full-term calves during parturition or shortly thereafter) and preweaning mortality. As we included full-term calves that were dead at the time of delivery in the numerator, we cannot exclude that some of these deaths represented stillbirths. Additionally, as ours was a retrospective study, ensuring data quality is more difficult than it would have been in a prospective study. It has been suggested that retrospective studies which include data from herds with no perinatal mortality (especially when herd size is $>100$ ) are likely to be underestimating perinatal mortality (Cuttance and Laven, 2019). Another limitation of our study was that both pollsters were veterinarians with experience in production medicine, which could have resulted in Hawthorne bias. Additionally, our study relied on farmer-reported information, which would also have inherent bias, considering that some of the information we gathered had animal welfare implications.

\section{CONCLUSIONS}

Several weaknesses in management practices that affect animal welfare in the prepartum and calf-rearing periods were identified in Uruguayan dairy farms. This could explain the high annual mortality risk for calves between birth and weaning. An effort should be made to improve data recording and analysis at the farm level; practices related to colostrum management, feeding, hygiene, biosecurity, and disinfection; and vaccinations. In addition, having suitable, motivated, and trained staff in the prepartum and calf-rearing sectors to care for the newborns and raise the calves under standardized procedures would be beneficial. Conducting extension efforts to the dissemination of good management practices in calf rearing, as well as developing national technologies that are made available to dairy farmers, are necessary tools to reinforce these concepts and to improve the outcome of calf rearing. Further research 
is needed on colostrum management, FTPI, and how potential risk factors affect calf mortality in Uruguayan dairy farms.

\section{ACKNOWLEDGMENTS}

The authors thank the veterinarians and farmers who participated in the survey, colleagues of the Facultad de Veterinaria de la Universidad de la República, Sociedad de Medicina Veterinaria de Uruguay, Instituto Nacional de la Leche (INALE) from Uruguay, and the Instituto Nacional de Tecnología Agropecuaria (INTA) Balcarce, Argentina, for critically reviewing the survey. We also thank Gabriel Mautone from the Uruguayan Ministerio de Ganadería, Agricultura y Pesca (MGAP), who collaborated with the selection of the farms included in the study. C. O. Schild and R. D. Caffarena acknowledge support from Instituto Nacional de Investigación Agropecuaria (INIA) and the Uruguayan Agencia Nacional de Investigación e Innovación (ANII) through graduate scholarships. This work was funded by grants N-15156 and N-23398 from INIA. The authors have not stated any conflicts of interest.

\section{REFERENCES}

Abuelo, A., P. Havrlant, N. Wood, and M. Hernandez-Jover. 2019. An investigation of dairy calf management practices, colostrum quality, failure of transfer of passive immunity, and occurrence of enteropathogens among Australian dairy farms. J. Dairy Sci. 102:8352-8366. https://doi.org/10.3168/jds.2019-16578.

Armengol, R., and L. Fraile. 2016. Colostrum and milk pasteurization improve health status and decrease mortality in neonatal calves receiving appropriate colostrum ingestion. J. Dairy Sci. 99:4718 4725. https://doi.org/10.3168/jds.2015-10728.

Bleul, U. 2011. Risk factors and rates of perinatal and postnatal mortality in cattle in Switzerland. Livest. Sci. 135:257-264. https://doi .org/10.1016/j.livsci.2010.07.022.

Caffarena, D. 2017. Aspectos clínicos y epidemiológicos de la diarrea neonatal en terneros de tambos de Uruguay y su asociación con infección por Cryptosporidium spp. y Escherichia coli F5 (K99+). MS Thesis. Facultad de Veterinaria, Universidad de la República. Montevideo Uruguay.

Casaux, L. 2018. Salmonella enterica en terneros lecheros de Uruguay: su rol como causal de enfermedad y mortalidad, caracterización de serotipos y resistencia a antibióticos. MS Thesis. Facultad de Veterinaria, Universidad de la República. Montevideo Uruguay.

Casaux, M. L., R. D. Caffarena, C. O. Schild, F. Giannitti, F. RietCorrea, and M. Fraga. 2019. Antibiotic resistance in Salmonella enterica isolated from dairy calves in Uruguay. Braz. J. Microbiol. 50:1139-1144. https://doi.org/10.1007/s42770-019-00151-w.

Castells, M., C. Schild, D. Caffarena, M. Bok, F. Giannitti, J. Armendano, F. Riet-Correa, M. Victoria, V. Parreño, and R. Colina. 2018. Prevalence and viability of group A rotavirus in dairy farm water sources. J. Appl. Microbiol. 124:922-929. https://doi.org/10 $.1111 /$ jam.13691.

Chase, C. C. L., D. J. Hurley, and A. J. Reber. 2008. Neonatal immune development in the calf and its impact on vaccine response. Vet. Clin. North Am. Food Anim. Pract. 24:87-104. https://doi.org/10 .1016/j.cvfa.2007.11.001.

Cuttance, E., and R. Laven. 2019. Estimation of perinatal mortality in dairy calves: A review. Vet. J. 252:105356. https://doi.org/10 $.1016 / \mathrm{j} . t v j 1.2019 .105356$.
Cuttance, E. L., W. A. Mason, R. A. Laven, J. McDermott, and C. Phyn. 2017a. Prevalence and calf-level risk factors for failure of passive transfer in dairy calves in New Zealand. N. Z. Vet. J. 65:297-304. https://doi.org/10.1080/00480169.2017.1361876.

Cuttance, E. L., W. A. Mason, J. McDermott, R. A. Laven, S. McDougall, and C. V. C. Phyn. 2017b. Calf and replacement heifer mortality from birth until weaning in pasture-based dairy herds in New Zealand. J. Dairy Sci. 100:8347-8357. https://doi.org/10 .3168/jds.2017-12793.

De Paula Vieira, A., V. Guesdon, A. M. de Passillé, M. A. G. von Keyserlingk, and D. M. Weary . 2008. Behavioral indicators of hunger in dairy calves. Appl. Anim. Behav. Sci. 109:180-189. https://doi .org/10.1016/j.applanim.2007.03.006.

de Vries, M., E. A. M. Bokkers, G. Van Schaik, B. Engel, T. Dijkstra, and I. J. M. Boer. 2014. Exploring the value of routinely collected herd data for estimating dairy cattle welfare. J. Dairy Sci. 97:715-730. https://doi.org/10.3168/jds.2013-6585.

Derks, M., T. van Werven, H. Hogeveen, and W. D. J. Kremer. 2014. Associations between farmer participation in veterinary herd health management programs and farm performance. J. Dairy Sci. 97:1336-1347. https://doi.org/10.3168/jds.2013-6781.

Donovan, G. A., I. R. Dohoo, D. M. Montgomery, and F. L. Bennett. 1998. Associations between passive immunity and morbidity and mortality in dairy heifers in Florida, USA. Prev. Vet. Med. 34:3146. https://doi.org/10.1016/S0167-5877(97)00060-3.

Drackley, J. K. 2008. Calf nutrition from birth to breeding. Vet. Clin. North Am. Food Anim. Pract. 24:55-86. https://doi.org/10.1016/ j.cvfa.2008.01.001.

Fariña, S. R., and P. Chilibroste. 2019. Opportunities and challenges for growth of milk production form pasture: The case of farm systems in Uruguay. Agric. Syst. 176:102631. https://doi.org/10 .1016/j.agsy.2019.05.001.

Flower, F. C., and M. D. Weary. 2001. Effects of early separation on the dairy cow and calf: 2 . Separation at 1 day and 2 weeks after birth. Appl. Anim. Behav. Sci. 70:275-284. https://doi.org/10 .1016/S0168-1591(00)00164-7.

Fruscalso, V., G. Olmos, and M. J. Hötzel. 2020. Dairy calves' mortality survey and associated management practices in smallholding, pasture-based herds in southern Brazil. Prev. Vet. Med. 175:104835. https://doi.org/10.1016/j.prevetmed.2019.104835.

Godden, S. M., J. P. Fetrow, J. M. Feirtag, L. R. Green, and S. J. Wells. 2005. Economic analysis of feeding pasteurized nonsaleable milk versus conventional milk replacer to dairy calves. J. Am. Vet. Med. Assoc. 226:1547-1554. https://doi.org/10.2460/javma.2005 .226 .1547 .

Godden, S. M., J. E. Lombard, and A. R. Woolums. 2019. Colostrum management for dairy calves. Vet. Clin. North Am. Food Anim. Pract. 35:535-556. https://doi.org/10.1016/j.cvfa.2019.07.005.

Gulliksen, S. M., K. I. Lie, and O. Østerås. 2009. Calf health monitoring in Norwegian dairy herds. J. Dairy Sci. 92:1660-1669. https:// doi.org/10.3168/jds.2008-1518.

Gundelach, Y., K. Essmeyer, M. K. Teltscher, and M. Hoedemaker. 2009. Risk factors for perinatal mortality in dairy cattle: Cow and foetal factors, calving process. Theriogenology 71:901-909. https:/ /doi.org/10.1016/j.theriogenology.2008.10.011.

Heinrichs, A. J., and B. S. Heinrichs. 2011. A productive study of calf factors affecting first-lactation and lifetime milk production and age of cow when removed from the herd. J. Dairy Sci. 94:336-341. https://doi.org/10.3168/jds.2010-3170.

Hötzel, M. J., C. Longo, L. F. Balcão, C. S. Cardoso, and J. H. C. Costa. 2014. A survey of management practices that influence performance and welfare of dairy calves reared in Southern Brazil. PLoS One 9:e114995. https://doi.org/10.1371/journal.pone.0114995.

INIA (Instituto Nacional de Investigación Agropecuaria). 2019. Sistema de Información Agroclimático (GRAS), Uruguay. Banco de datos agroclimáticos. Accessed Mar. 15, 2018. http://www.inia.uy/ gras/Clima/Banco-datos-agroclimatico.

Instituto Nacional de la Leche (INALE). 2019. Informe 2018. Acessed Aug. 10, 2018 https://www.inale.org/informes/situacion-y -perspectivas-ano-2018/. 
INTA CeRBAS (Instituto Nacional de Tecnología Agropecuaria, Centro Regional Buenos Aires Sur). 2011. Caracterización de sistemas de crianza de terneras en tambos en el área del CeRBAS. Pages 1-13. Proyecto regional de lechería EEA Cuenca del Salado, Buenos Aires. Ediciones INTA, Mar del Plata, Argentina.

Jenny, B. F., G. E. Gramling, and T. M. Glaze. 1981. Management factors associated with calf mortality in South Carolina dairy herds. J. Dairy Sci. 64:2284-2289. https://doi.org/10.3168/jds S0022-0302(81)82843-3.

Jorgensen, M. W., A. Adams-Progar, A. M. de Passillé, J. Rushen, J. A. Salfer, and M. I. Endres. 2017. Mortality and health treatment rates of dairy calves in automated milk feeding systems in the Upper Midwest of the United States. J. Dairy Sci. 100:9186-9193. https://doi.org/10.3168/jds.2017-13198.

Kayano, M., M. Kadohira, and M. A. Stevenson. 2016. Risk factors for stillbirths and mortality during the first $24 \mathrm{~h}$ of life on dairy farms in Hokkaido, Japan 2005-2009. Prev. Vet. Med. 127:50-55. https:/ /doi.org/10.1016/j.prevetmed.2016.03.012

Kertz, A. F., T. M. Hill, J. D. Quigley III, A. J. Heinrichs, J. G. Linn, and J. K. Drackley. 2017. A 100-year review: Calf nutrition and management. J. Dairy Sci. 100:10151-10172. https://doi.org/10 $.3168 /$ jds. $2017-13062$.

Khan, M. A., D. M. Weary, and M. A. G. Von Keyserlingk. 2011. Invited review: Effects of milk ration on solid feed intake, weaning, and performance in dairy heifers. J. Dairy Sci. 94:1071-1081. https://doi.org/10.3168/jds.2010-3733.

Le Cozler, Y., O. Recourse, E. Ganche, D. Giraud, J. Danel, M. Bertin, and P. Brunschwig. 2012. A survey on dairy heifer farm management practices in a Western-European plainland, the French Pays de la Loire region. J. Agric. Sci. 150:518-533. https://doi.org/10 $.1017 /$ S0021859612000032.

Lorenz, I., J. F. Mee, B. Earley, and S. J. More. 2011. Calf health from birth to weaning. I. General aspects of disease prevention. Ir. Vet. J. 64:10. https://doi.org/10.1186/2046-0481-64-10.

Lundborg, G. K., E. C. Svensson, and P. A. Oltenacu. 2005. Herdlevel risk factor for infectious diseases in Swedish dairy calves aged 0-90 days. Prev. Vet. Med. 68:123-143. https://doi.org/10.1016/j .prevetmed.2004.11.014.

Marcé, C., R. Guatteo, N. Bareille, and C. Fourichon. 2010. Dairy calf housing systems across Europe and risk for calf infectious diseases. Animal 4:1588-1596. https://doi.org/10.1017/S1751731110000650.

McGuirk, S. M. 2008. Disease management of dairy calves and heifers Vet. Clin. North Am. Food Anim. Pract. 24:139-153. https://doi .org/10.1016/j.cvfa.2007.10.003.

McGuirk, S. M., and M. Collins. 2004. Managing the production, storage and delivery of colostrum. Vet. Clin. North Am. Food Anim. Pract. 20:593-603. https://doi.org/10.1016/j.cvfa.2004.06.005.

Mee, J. F. 2008. Newborn dairy calf management. Vet. Clin. North Am. Food Anim. Pract. 24:1-17. https://doi.org/10.1016/j.cvfa 2007.10.002.

Mee, J. F., C. Sánchez-Miguel, and M. Doherty. 2014. Influence of modifiable risk factors on the incidence of stillbirth/perinatal mortality in dairy cattle. Vet. J. 199:19-23. https://doi.org/10.1016/ j.tvil.2013.08.004.

MGAP-DICOSE (Ministerio de Ganadería Agricultura y Pesca, Dirección General de Servicio Ganaderos, Dirección Contralor de Semovientes). 2013. Declaración Jurada de Lechería de 2013. March 12, 2016 http://www.mgap.gub.uy/dgsg/DICOSE/ DatosDJ_2013.html.

MGAP-DIEA (Ministerio de Ganadería. Agricultura y Pesca, Oficina de Estadísticas Agropecuarias). 2019. Producción animal: lechería comercial. August 17, 2019. https://descargas.mgap.gub.uy/ DIEA/Anuarios/Anuario2019/Anuario2019.pdf

National Research Council (NRC). 2001. Nutrient requirements of the young calf. Pages 214-223 in Nutrient Requirements of Dairy Cattle, 7th rev. ed. Natl. Acad. Press, Washington, DC. https:// doi.org/https://doi.org/10.17226/9825.

Neto, R. M., C. E. Faroni, P. Pauletti, and R. Bessi. 2004. A survey about dairy calf husbandry: Performance and passive immunity. Accessed Jul. 2020. http://www.scielo.br/pdf/rbz/v33n6s3/23435 .$p d f$
Nyman, A. K., A. Lindberg, and C. H. Sandgren. 2011. Can precollected register data be used to identify dairy herds with good cattle welfare? Acta Vet. Scand. 53(S1):S8. https://doi.org/10 .1186/1751-0147-53-S1-S8.

FAO-FEPALE (Organización de las Naciones Unidas para la Alimentación y la Agricultura y Federación Panamericana de Lechería). 2011. Situación de la lechería en América Latina y el Caribe. Accessed Apr. 25, 2016. http://www.fao.org/fileadmin/templates/ est/COMM_MARKETS_MONITORING/Dairy/Documents/ Paper_Lecher\%C3\%ADa_AmLatina_2011.pdf

Raboisson, D., F. Delor, E. Cahuzac, C. Gendre, P. Sans, and G. Allaire. 2013. Perinatal, neonatal, and rearing period mortality of dairy calves and replacement heifers in France. J. Dairy Sci 96:2913-2924. https://doi.org/10.3168/jds.2012-6010.

Rodríguez, A. R., J. A. Maiztegui, and M. A. Allassia. 2011. Sistemas de Crianza, pages 68-117 in Crianza Artificial de Terneros, un Real Desafío Tecnológico. 2da ed. Fondo Editor Allignani. Santa Fe, Argentina.

Sandgren, C. H., A. Lindberg, and L. J. Keeling. 2009. Using a national dairy database to identify herds with poor welfare. Anim. Welf. 18:523-532.

Santman-Berends, I. M. G. A., Y. H. Schukken, and G. van Schaik. 2019. Quantifying calf mortality on dairy farms: Challenges and solutions. J. Dairy Sci. 102:6404-6417. https://doi.org/10.3168/ jds.2019-16381.

Schuenemann, G. M., S. Bas, E. Gordon, and J. D. Workman. 2013. Dairy calving management: description and assessment of training program for dairy personnel. J. Dairy Sci. 96:2671-2680. https:// doi.org/10.3168/jds.2012-5976.

Schuenemann, G. M., I. Nieto, S. Bas, K. N. Galvão, and J. Workman. 2011. Assessment of calving progress and reference times for obstetrics intervention during dystocia in Holstein dairy cows. J. Dairy Sci. 94:5494-5501. https://doi.org/10.3168/jds.2011-4436.

Seppä-Lassila, L., K. Sarjokari, M. Hovinen, T. Soveri, and M. Norring. 2016. Management factors associated with mortality of dairy calves in Finland: A cross sectional study. Vet. J. 216:164-167. https://doi.org/10.1016/j.tvjl.2016.07.008.

Soberon, F., and M. E. Van Amburgh. 2013. Lactation biology symposium: The effect of nutrient intake from milk or milk replacer of preweaned dairy calves on lactation milk yield as adult: A meta-analysis of current data. J. Anim. Sci. 91:706-712. https://doi .org $/ 10.2527 /$ jas. 2012-5834.

Stewart, S., S. Godden, R. Bey, P. Rapnicki, J. Fetrow, R. Farnsworth, M. Scanlon, Y. Arnold, L. Clow, K. Mueller, and C. Ferroullet. 2005. Preventing bacterial contamination and proliferation during the harvest, storage, and feeding of fresh bovine colostrum. J. Dairy Sci. 88:2571-2578. https://doi.org/10.3168/jds.S0022 -0302(05)72933-7.

Stull, C., and J. Reynolds. 2008. Calf welfare. Vet. Clin. North Am. Food Anim. Pract. 24:191-203. https://doi.org/10.1016/j.cvfa .2007.12.001.

Sumner, C. L., and M. A. G. Von Keyserlingk. 2018. Canadian dairy cattle veterinarian perspectives on calf welfare. J. Dairy Sci. 101:10303-10316. https://doi.org/10.3168/jds.2018-14859.

Svensson, C., A. Linder, and S. O. Olsson. 2006. Mortality in Swedish dairy calves and replacement heifers. J. Dairy Sci. 89:4769-4777. https://doi.org/10.3168/jds.S0022-0302(06)72526-7.

Torsein, M., A. Lindberg, C. H. Sandgren, K. P. Waller, M. Törnquist, and C. Svensson. 2011. Risk factors for calf mortality in large Swedish dairy herds. Prev. Vet. Med. 99:136-147. https://doi.org/ 10.1016/j.prevetmed.2010.12.001.

USDA (United States Department of Agriculture). 2007. Heifer calf and management practices on U.S. dairy operations. Accessed Sept. 24, 2016. https://www.aphis.usda.gov/animal_health/ nahms/dairy/downloads/dairy07/Dairy07_ir_CalfHealth.pdf.

USDA (United States Department of Agriculture). 2014. Dairy cattle management practices in the United States. Acessed Sept. 24, 2016 https://www.aphis.usda.gov/animal_health/nahms/dairy/ downloads/dairy14/Dairy14_dr_PartI.pdf.

Urie, N. J., J. E. Lombard, C. B. Shivley, C. A. Kopral, A. E. Adams, T. J. Earleywine, J. D. Olson, and F. B. Garry. 2018. Preweaned 
heifer management on US dairy operations: Part V. Factors associated with morbidity and mortality in preweaned dairy heifer calves. J. Dairy Sci. 101:9229-9244. https://doi.org/10.3168/jds 2017-14019

Vasseur, E., F. Borderas, R. I. Cue, D. Lefebvre, D. Pellerin, J. Rushen. K. M. Wade, and A. M. de Passille. 2010. A survey of dairy calf management practices in Canada that affect animal welfare. J. Dairy Sci. 93:1307-1316. https://doi.org/10.3168/jds.2009-2429.

Vasseur, E., J. Rushen, and A. M. de Passillé. 2009. Does a calf's motivation to ingest colostrum depend on time since birth, calf vigor or provision of heat? J. Dairy Sci. 92:3915-3921. https://doi.org/ $10.3168 /$ jds.2008-1823.

Villettaz Robichaud, M., A. M. de Passillé, D. L. Pearl, S. J. LeBlanc, S. M. Godden, D. Pellerin, E. Vasseur, J. Rushen, and D. B. Haley. 2016. Calving management practices on Canadian dairy farms: Prevalence of practices. J. Dairy Sci. 99:2931-2404. https://doi .org/10.3168/jds.2015-9641.

von Keyserlingk, M. A. G., and D. M. Weary. 2007. Maternal behavior in cattle. Horm. Behav. 52:106-113. https://doi.org/10.1016/j yhbeh.2007.03.015.

Weary, D. M., and B. Chua. 2000. Effects of early separation on the dairy cow and calf: 1 . Separation at $6 \mathrm{~h}, 1$ day and 4 days af- ter birth. Appl. Anim. Behav. Sci. 69:177-188. https://doi.org/10 .1016/S0168-1591(00)00128-3.

Wells, S. J., L. P. Garber, and G. W. Hill. 1996. Health status of preweaned dairy heifers in the United States. Prev. Vet. Med. 29:185199. https://doi.org/10.1016/S0167-5877(96)01078-1.

Woolums, A. R., B. B. Karisch, J. G. Frye, W. Epperson, D. R. Smith, J. Blanton Jr., F. Austin, R. Kaplan, L. Hiott, T. Woodley, S. K. Gupta, C. R. Jackson, and M. McClelland. 2018. Multidrug resistant Mannheimia haemolytica isolated from high-risk beef stocker cattle after antimicrobial metaphylaxis and treatment for bovine respiratory disease. Vet. Microbiol. 221:143-152. https://doi.org/ 10.1016/j.vetmic.2018.06.005

\section{ORCIDS}

Carlos O. Schild ๑ https://orcid.org/0000-0002-7851-3039

Rubén D. Caffarena @ https://orcid.org/0000-0002-2141-3264

Andrés Gil @ https://orcid.org/0000-0003-0006-5640

Federico Giannitti ๑ https://orcid.org/0000-0001-8799-6848 